\title{
DEVELOPMENT OF WAFFLE WITH FAT FILLING USING UNCONVENTIONAL VEGETABLE RAW MATERIALS
}

\section{Oksana Haponceva ${ }^{1}$, Nataliia Cherevychna ${ }^{2}$, Oxana Balashcova ${ }^{3}$, Alla Nikolaenko-Lomakina, Nataliia Ashtaieva ${ }^{5}$, Tetiana Popova ${ }^{6}$, Olena Skyrda7, Viktoria Kolesnyk ${ }^{8}$}

${ }^{1}$ Department of Food Technology, Hotel and Restaurant Business, Kharkiv College of Trade and Economics, Kyiv National University of Trade and Economics, Kharkiv, Ukraine ok_gap@ukr.net

ORCID: https://orcid.org/0000-0003-3959-4689

${ }^{2}$ Department of Public Administration and Entrepreneurship, National Aerospace University «Kharkiv Aviation Institute», Kharkiv, Ukraine cherevichna@gmail.com

ORCID: https://orcid.org/0000-0002-6660-5366

${ }^{3}$ Department of Food Technology, Hotel and Restaurant Business, Kharkiv College of Trade and Economics, Kyiv National University of

Trade and Economics, Kharkiv, Ukraine

astaeva553@gmail.com

ORCID: https://orcid.org/0000-0002-5711-2279

${ }^{4}$ Department of Food Technology, Hotel and Restaurant Business, Kharkiv College of Trade and Economics, Kyiv National University of

Trade and Economics, Kharkiv, Ukraine

a0999690711@gmail.com

ORCID: https://orcid.org/0000-0002-4047-1646

${ }^{5}$ Department of Food Technology, Hotel and Restaurant Business, Kharkiv College of Trade and Economics, Kyiv National University of

Trade and Economics, Kharkiv, Ukraine

astaeva553@gmail.com

ORCID: https://orcid.org/0000-0001-6740-848X

${ }^{6}$ Department of Merchandising and Goods Expertize, Kharkiv State University of Food Technology and Trade, Kharkiv, Ukraine

popova.tatyana1@gmail.com

ORCID: https://orcid.org/0000-0001-5984-1558

${ }^{7}$ Department of Restaurant Technology and Ayurvedic Products, National University of Food Technologies, Kyiv, Ukraine

sheva-forever@ukr.net

ORCID: https://orcid.org/0000-0002-1481-270X

${ }^{8}$ Department of Commodities in Customs, Kharkiv State University of Food Technology and Trade, Kharkiv, Ukraine

vko1240584@gmail.com

ORCID: https://orcid.org/0000-0003-3178-9801

ARTICLE INFO

Article history:

Received date 22.03.2021

Accepted date 20.04.202

Published date 30.04.2021

Section:

Food Science

D O I

$10.21303 / 2313-8416.2021 .001802$

KEYWORDS

waffles

carob powder

waffle storage

apple powder

quality assessment

\section{ABSTRACT}

The object of research: technology for the production of waffles of increased consumer value with a fat filling using non-traditional plant raw materials.

Investigated problem: the problem of the production of new waffles is solved by using a mixture of vegetable-butter and coconut oil, dry skim milk, carob powder, apple powder, cinnamon and ascorbic acid.

Main scientific results: The use of non-traditional raw materials in the fatty filling of waffles increases the organoleptic properties of the products. Waffles have a pleasant taste and aroma due to the content of carob powder, apple powder and cinnamon in the filling. Due to the introduction of unconventional raw materials and herbal additives into the formulations of new products, the amount of total sugars was reduced. The mass fraction of fat also decreased due to the replacement of confectionery fat for waffle fillings with a vegetable-butter mixture and coconut oil. The moisture content of new samples of waffles and waffle sheets is within the established norms. It was found that the finished waffles meet the requirements of the state standard for physical and chemical indicators. The developed score helped to establish that the quality level of the developed waffles is 0.97 .

The area of practical use of the research results: food industry enterprises specializing in the production of confectionery.

An innovative technological product: the technology for the production of waffles with a fat filling using non-traditional plant raw materials makes it possible to obtain a new confectionery product of increased consumer value with a balanced composition and high organoleptic properties.

Scope of application of the innovative technological product: confectionery production of dietary products.

(C) The Author(s) 2021. This is an open access article under the Creative Commons CC BY license

\section{Introduction}

Waffles occupy an important place in the range of flour confectionery products, characterized by a varied composition, high organoleptic properties and unstable stability during long-term 
storage. The quality and consumer properties of waffles largely depend on the characteristics of the main and auxiliary raw materials.

Analysis of the chemical composition of waffles with fatty fillings indicates their imbalance, which is associated with a high content of carbohydrates and fats, and a relatively low content of proteins, dietary fiber, vitamins, minerals and other biologically active substances. Therefore, the issue of developing waffles with improved consumer properties is relevant. A promising direction for creating waffles of increased biological value is the inclusion of non-traditional raw materials and other herbal additives in their recipe composition. Thanks to this, it is possible to enrich products with vitamins, minerals, dietary fiber, and other biologically active compounds.

\section{1. The object of research}

The object of research is the technology of waffles with fat filling using non-traditional vegetable raw materials.

Waffles occupy an important place in the assortment of flour confectionery products. A promising direction for creating waffles of increased consumer value is the inclusion of unconventional raw materials and other herbal additives in their recipe composition. The leading direction of improving the technology of waffle products is the inclusion of various non-traditional additives in the formulation of waffle sheets and fillings: processed products of legumes, dairy products, fruit and vegetable and medicinal-technical raw materials and various vitamin and mineral premixes.

\section{2. Problem description}

Scientists are constantly looking for ways to improve the recipe composition and increase the consumer value of waffles.

To improve consumer properties and biological value in confectionery products, the expediency of using buckwheat, corn, pea, food sunflower flour, as well as extruded cereals, corn flakes and the like has been proven. For example, it was found that the optimal ratio of wheat flour to amaranth flour in recipes for leaf waffles should be 80:20 [1]. The addition of peeled rye, barley and buckwheat flour in combination with other natural additives allows to increase the protein content up to $30 \%$, reduce the amount of carbohydrates by $2.0 \%$, and the amount of fat - up to $15.0 \%[2,3]$.

The introduction of Jerusalem artichoke powder to the waffle leaf formulation made it possible to enrich the product with protein substances, B vitamins, ascorbic acid, as well as the polysaccharide inulin, which makes it possible to recommend the product for consumption by people with diabetes [4].

Scientists proposed to introduce the following components into the recipe: pollen, honey, extruded bean flour, powders of black elderberry flowers and heart-leaved linden, thick-leaved bergenia, and cranberries. The developed waffles are distinguished by a high content of protein substances and a reduced amount of carbohydrates and fats [5].

The introduction of fruit and vegetable powders (for example, from apples, grapes, rose hips, beets, carrots, pumpkin, cabbage, dill, Caucasian wild pear and German medlar) into the composition of waffle fillings leads to an increase in the content of vitamin $C, \beta$-carotene in finished products, potassium, iron, fiber and pectin and antioxidant substances $[6,7]$.

Scientists have developed "Zabava" waffles for dietary use, in the formulation of which stevioside is introduced (reducing the product's sucrose content), unlit beet fibers (a source of fiber and pectin substances) and dry whey (a source of protein and calcium) [1].

It is advisable to introduce various vitamin and mineral mixtures (for example, Valetek-5) into the fatty fillings of waffles [7].

In order to increase the stability of waffles during storage, green tea extract is used, which has a positive effect on the rheological properties of waffle dough. This is due to the content of a large amount of polyphenolic substances [8]. The use of turmeric, blackberry and pomace of blue grapes has been proposed, which have high antioxidant properties and have a positive effect on the stabilization of fats in confectionery products $[1,9]$. 


\section{3. Suggested solution to the problem}

The problem of producing waffles with increased consumer value can be solved by using new functional ingredients along with traditional raw materials. This will expand the range, improve the quality and safety of products, and obtain products of increased biological and consumer value with high organoleptic properties.

Therefore, it can be argued that the leading direction is the inclusion of various non-traditional additives in the formulation of waffle sheets and fillings: processed products of legumes, dairy products, fruit and vegetable and medicinal and technical raw materials and various vitamin and mineral premixes.

The aim of research is to study the consumer properties of the developed waffles with fat filling using unconventional herbal additives.

\section{Materials and methods}

According to the traditional recipe, waffles with fat filling (for example, Artek waffles) include: wheat bean, egg products, salt, soda and water (for waffle sheets); powdered sugar, confectionery fat, cocoa powder, dry fat milk, vanilla essence and waffle leaf crumbs (for fat filling).

In order to increase the consumer value of waffles, a new recipe is proposed with the introduction of unconventional raw materials containing biologically active substances and antioxidant compounds. As a result of the literature review, the following were chosen as raw materials for the production of fat filling for new waffles: mixtures of vegetable-butter and coconut oil, skimmed milk powder, carob powder, apple powder, cinnamon and ascorbic acid.

The study of the organoleptic and physicochemical characteristics of waffles was carried out according to standard methods using modern methods using equipment.

The quality assessment was carried out according to DSTU 4033-2001 "Waffles. General technical conditions "[10].

Determined the mass fraction of moisture, mass fraction of fat, protein substances, sugars, acid and peroxide values of fat, microbiological purity according to the approved methods [11].

Research methods of physical and chemical quality indicators:

- mass fraction of moisture - by drying to constant weight at a temperature of $105^{\circ} \mathrm{C}$ in accordance with DSTU 4910;

- mass fraction of total sugars - Permanganate method (according to Bertrand) according to DSTU 5059;

- mass fraction of fat - by the extraction-weight method (according to Soxhlet) in accordance with DSTU 5060;

- massfraction of protein substances - by the amount of nitrogen by the Kjeldahl method according to DSTU ISO 1871:2003.

The chemical composition was determined using a standard calculation method [11].

The organoleptic assessment of the quality of new waffles was carried out in accordance with the requirements of DSTU 4033-2001 [10] and using 90-factors taken into account in your quality assessment scale and includes the following indicators: appearance, color, appearance at break, filling quality, taste and smell. This system was taken as a basis and improved by introducing new significant quality indicators - the severity and harmony of the additive, the harmony of the combination of the waffle leaf filling and the aftertaste. The system taken into account in your rating provides for evaluating the quality of waffles as "excellent", "good", "satisfactory" and "unsatisfactory". For each indicator, a coefficient of significance was determined with respect to its impact on the quality of the product. The overall quality index was calculated using the formula:

$$
X=a_{1} B_{1}+a_{2} B_{2}+\ldots+a_{n} B_{n}
$$

where $a$-coefficient of significance of a single indicator; $B$-score in points of a single indicator.

\section{Results}

An important feature in the development of waffle formulations is the use of non-traditional raw materials, namely in the composition of the fat filling, since it is subjected to heat treatment, 
which means that all biologically valuable substances and composition remain in their natural form without being destroyed. When developing compositions of fatty fillings for waffles, the dosage of the components was determined as the most optimal for obtaining a product with harmonious organoleptic properties.

So, apple powder contains $12.9 \%$ fiber and $6.9 \%$ pectin substances, as well as potassium, iron, iodine, niacin, riboflavin, thiamine and vitamin C. Carob powder contains sugars $-48 \ldots 56 \%$, proteins $-3 \ldots 8 \%$, mineral elements $-2 \ldots 3 \%$ (iron, potassium, magnesium, calcium), fats $-0.2 \ldots 0.6$, vitamins A, B, B2, B3 and D. It is not has special contraindications, but it contains a lot of sucrose, therefore it is excluded from the diet for diabetes mellitus.

A vegetable-butter mixture and coconut oil were used as the fatty base of the waffle fillings compositions. The vegetable-butter mixture is a substitute for milk fat and contains vegetable fats and oils in a natural and hardened state, demineralized milk whey, butter, anhydrous milk fat (10.5\% of the fat mass) and lactose. Coconut oil contains saturated and polyunsaturated fatty acids, calcium, phosphorus and vitamin E.

In order to enrich the product with high-grade animal proteins and minerals, the amount of skimmed milk powder in the filling recipe was increased.

In order to prevent fat oxidation in waffle fillings, it is advisable to use cinnamon. It contains 5-65\% cinnamaldehyde, $4 \ldots 18 \%$ eugenol, essential oils, tannins with powerful antioxidant properties. To increase the antioxidant effect of natural additives, ascorbic acid was also added to the fat fillings.

Thus, the use of non-traditional raw materials in the production of new waffles with fatty fillings can increase the nutritional and biological value of the product and extend their shelf life.

Using the method of food combinatorics, a recipe for new waffles with non-traditional raw materials was compiled. The recipe for waffles with unconventional raw materials is shown in Table 1.

Table 1

Recipe composition of waffles with unconventional raw materials

\begin{tabular}{cc}
\hline Component & Quantity, \% \\
\hline Wheat flour grade A & 24.4 \\
Egg yolks & 2.1 \\
Table salt & 0.1 \\
Baking soda & 0.1 \\
Powdered sugar & 15.0 \\
Vegetable-creamy mixture & 24.7 \\
Coconut oil & 7.9 \\
Skimmed milk powder & 13.6 \\
Apple powder & 5.0 \\
Carob powder & 4.0 \\
Ground cinnamon & 1.0 \\
Vanilla essence & 0.1 \\
Ascorbic acid & 0.2 \\
Total & 100
\end{tabular}

The study of organoleptic properties was carried out according to the system developed by us and taking into account the requirements of DSTU 4033-2001 [10]. The results are shown in Table 2.

Physicochemical indicators of the quality of new waffles were determined in accordance with the normative document DSTU 4033-2001 [10]. The results of the study are shown in Table 3.

The main indicator of the quality of food is the chemical composition, which forms the nutritional and energy value. The results of calculating the chemical composition are shown in Table 4. 
Table 2

Organoleptic evaluation of developed waffles

\begin{tabular}{ccc}
\hline Level of quality & Weighting factor & Waffle rating \\
\hline 1. Appearance & 1 & $5.0 \pm 0.25$ \\
1. . Shape & 1 & $4.9 \pm 0.25$ \\
1. 2. Size & 1 & $5.0 \pm 0.25$ \\
1. 3. Surface & & $4.9 \pm 0.25$ \\
2. Color & 1 & $5.0 \pm 0.25$ \\
2. 1. Waffle sheet color & 1 & $7.5 \pm 0.45$ \\
2. 2. Filling color & & $4.8 \pm 0.24$ \\
3. Break level & 1,5 & $5.0 \pm 0.25$ \\
3. 1. Waffle sheet quality & 1 & $6.75 \pm 0.38$ \\
3. 2. Consistency & 1 & $9.2 \pm 0.43$ \\
3. 3. Filling distribution & 1,5 & $9.8 \pm 0.48$ \\
4. Filling quality & 2 & $5.0 \pm 0.25$ \\
5. Smell & 2 & $5.0 \pm 0.25$ \\
6. Taste & 25 & $4.4 \pm 0.22$ \\
6. 1. Severity of the additive & 1 & $4.8 \pm 0.24$ \\
6. 2. Harmony & 1 & $87.05 \pm 4.44$ \\
6. 3. Aftertaste & 1 & $5.81 \pm 0.30$
\end{tabular}

Table 3

Physicochemical indicators of the quality of the developed waffles

\begin{tabular}{|c|c|c|}
\hline Indicator & $\begin{array}{l}\text { Norm according to } \\
\text { GOST 4033-2001 }\end{array}$ & $\begin{array}{l}\text { Research results of } \\
\text { developed waffles }\end{array}$ \\
\hline Mass fraction of total sugar by sucrose (In terms of dry matter), $\%$ & $20.0-54.3$ & $22.81 \pm 1.0$ \\
\hline Mass fraction of fat (In terms of dry matter), $\%$ & $21.8-41.8$ & $29.79 \pm 1.0$ \\
\hline Mass fraction of moisture, $\%$ & $0.5-7.8$ & $2.48 \pm 0.5$ \\
\hline $\begin{array}{c}\text { Mass fraction of ash insoluble in solution with a mass fraction of } \\
\text { hydrochloric acid } 10 \%, \%\end{array}$ & No more than 0.1 & $0.1 \pm 0.01$ \\
\hline
\end{tabular}

Table 4

The chemical composition of waffles from non-traditional raw materials

\begin{tabular}{cc}
\hline Indicator & Content \\
\hline Mass fraction of fats, \% & $29.46 \pm 1.0$ \\
Mass fraction of proteins, & $4.11 \pm 0.5$ \\
Mass fraction of carbohydrates: & $56.6 \pm 1.5$ \\
- Total (\%) & $22.81 \pm 1.0$ \\
- sugars (\%) & $1.36 \pm 0.01$ \\
Mass fraction of ash, \% & $2.48 \pm 0.5$ \\
Energy value, kcal/100 g & 507.98
\end{tabular}

\section{Discussion of results}

The use of unconventional raw materials in the fatty filling of new waffles made it possible to increase the organoleptic properties of the products. Waffles have a pleasant taste and aroma due 
to the content of carob powder, apple powder and cinnamon in the filling. The developed waffle sample was rated "excellent" in terms of organoleptic characteristics.

The introduction of non-traditional plant raw materials into the waffle formulation led to a significant decrease in the carbohydrate content in the developed waffles. Their number decreased by $13 \%$ compared to traditional products, due to a decrease in the amount of wheat flour and powdered sugar. The inclusion of an increased amount of skimmed milk powder in the fatty fillings of the waffles increased the protein content in the new waffles. The amount of fat in new waffle samples is almost $10 \%$ lower than traditional waffle products (due to the replacement of confectionery fat with a vegetable-butter mixture and coconut oil). The moisture content of new samples of waffles and waffle sheets is within the limits established by law.

The use of non-traditional ingredients for waffle fillings affects not only the quantitative, but also the qualitative composition of the waffles. The increase in the consumer value of the developed waffles is due to the selection of appropriate raw materials and is determined by the amino acid, fatty acid, mineral and vitamin composition.

It is found that the strongest aspects of the developed waffles are: the uniqueness of the proposals, improved consumer characteristics, reduced calorie content and increased shelf life. The weak side of the development is the low level of information content of consumers about new products and the risks of manufacturers from the introduction of innovative technology into production.

The prospect for further research is to determine the dynamics of the safety of the developed waffles in various types of consumer packaging.

\section{Conclusions}

The expediency of using herbal additives - carob powder, apple powder, cinnamon and ascorbic acid in the formulation of fat filling for waffle products - has been proven. With the help of the developed ones taken into account in your rating, it was determined that the quality level of the developed waffles is 0.97 . The use of unconventional raw materials in the fatty filling of new waffles made it possible to increase the organoleptic properties of the products. Samples of the developed waffles were rated high in taste and smell. Waffles have a pleasant taste and aroma due to the content of carob powder, apple powder and cinnamon in the filling. The developed waffles meet the requirements of the state standard for organoleptic and physicochemical indicators. It is proved that the increase in the consumer value of the developed waffles is due to the selection of appropriate raw materials and is determined by the amino acid, fatty acid, mineral and vitamin composition.

\section{References}

[1] Lozova, T., Syrokhman, I. (2017). Naukove obgruntuvannia polipshennia spozhyvnykh vlastyvostei boroshnianykh kondyterskykh vyrobiv z vykorystanniam pryrodnoi netradytsiinoi syrovyny. Lviv: Vydavnytstvo Lvivskoho torhovelno-ekonomichnoho universytetu, 328.

[2] Mineeva, A. A., Timofeenko, T. I., Kucheryavenko, I. M., Mkhitaryants, L. A., Filenkova, M. V., Sheyko, A.I. (2014). Development of sheet wafers formulations of functional purpose with wholemeal flour from amaranth seeds. Food Technology, 4, 55-57.

[3] Soldatova, E. A., Misteneva, S. Iu., Savenkova, T. V., Taleisnik, M. A. (2015). Implementation of the theoretical and practical aspects of competitive wafers production for confectionery. Kondyterskoe proyzvodstvo, 3, 17-21.

[4] Pakhomova, I. (2015). The impact of non-traditional raw matherials on wafers quality dring storage. Khlibopekarska i kondyterska promyslovist Ukrainy, 7-8 (128-129), 7-11.

[5] Lozovaia, T. M. (2014). Improved consumer properties of wafers using non-traditional raw materials. Eastern-European Journal of Enterprise Technologies, 2 (12 (68)), 108-113. doi: http://doi.org/10.15587/1729-4061.2014.23356

[6] Skobelskaia, Z. H., Honcharuk, Y. V., Solovarova, A. E. (2016). Expanding the Range of Wafers of Prophylactic Purpose. Pyshchevaia promeshlennost, 9, 20-22.

[7] Shydlovska, O., Dotsenko, V., Medvid, I., Protyven, A. (2015). Zastosuvannia poroshku z yahid ozhyny v tekhnolohiiakh boroshnianykh kondyterskykh vyrobiv. Khlibopekarska i kondyterska promyslovist Ukrainy, 12, 10-14.

[8] Sirohman, I. V., Pakhomova, I. V. (2015). Improving the consumer properties of new wafers. Entrepreneurship and trade, 18, 85-89.

[9] Dorohovych, V., Hrytsevich, M., Isakova, N. (2018). Effect of gluten free flour on sensory, physic-chemical, structural and mechanical properties of wafer batter and waffles. Ukrainian Food Journal, 2 (7), 253-263. doi: http://doi.org/10.24263/2304-974x-2018-7-2-8

[10] Vafli. Zahalni tekhnichni umovy: DSTU 4033-2018 (2018). Kyiv: Derzhspozhyvstandart Ukrainy, 12.

[11] Lomnytska, Ya., Vasylechko, V. (2017). Metody analizu obiektiv dovkillia. Khimichnyi sklad produktiv kharchuvannia ta yikh analiz. Chastyna 2. Lviv: LNU imeni Ivana Franka, 116. 